\title{
Sengketa Tanah Wakaf di Sumatera Utara (Systematic Literature Review Terhadap Pemberitaan Media Online)
}

\author{
Waqf Land Dispute in North Sumatra (Systematic Literature Review of Online \\ Media News)
}

\author{
Akmaluddin Syahputra1, Khalid ${ }^{2}$ \\ 1. Fakultas Syari'ah dan Hukum UIN Sumatera Utara Medan, Indonesia. \\ E-mail: dr.akmalsyahputra@gmail.com \\ 2. Fakultas Syari'ah dan Hukum UIN Sumatera Utara Medan, Indonesia. E-mail: khalid@uinsu.ac.id
}

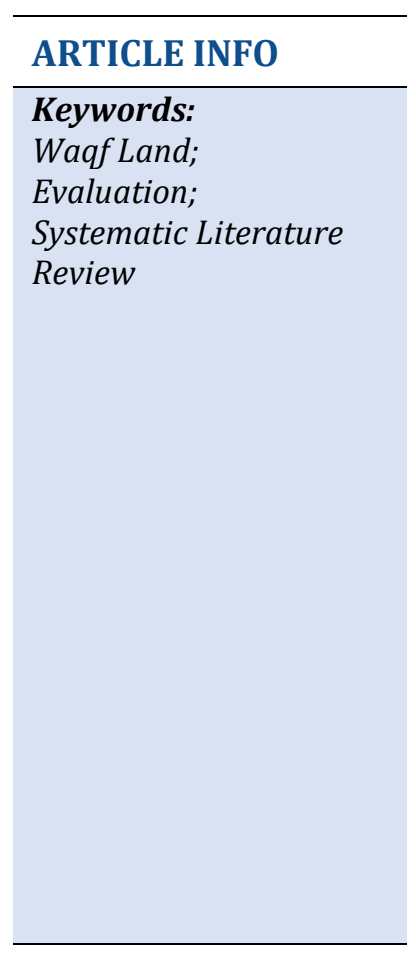

\section{INFO ARTIKEL}

Kata kunci:
Tanah Wakaf;
Evaluasi;
Systematic Literature
Review

\begin{abstract}
The focus of this research is to assess media content about the Waqf Land dispute in North Sumatra. This study aims to identify useful information regarding waqf land disputes in Sumatra sourced from online media that can be accessed on the internet, carried out from 31 July 2019-30 November 2019. The method used in this study Systematic literature review (SLR), the method of literature review that identifies, evaluates, and interprets all findings on a research topic to answer research questions. The final results obtained in this study indicate that based on the news coverage of 48 media reporting waqf disputes from 2007 to 2019, there are at least certain significant criteria based on the protocol established in this study: First, in terms of endowment designation, waqf land disputes are dominated by mosque; Second, in terms of the disputing parties, it is dominated by Muslims and the developers; Third: in terms of location in North Sumatra, dominated in Medan City; Fourth: from the year of publication dominated in 2018; and Fifth, from the media code point of view, it is not dominated by certain media characters, which means that both Islamic media, mainstream media, local and national media, equally contain the reporting of waqf disputes. The results of an evaluation of waqf dispute data revealed by the media indicate that, in general, the issue of waqf disputes in North Sumatra has not been fully described in each region. Advocacy carried out both litigation and non-litigation shows there has not been a complete resolution of the waqf land dispute in North Sumatra.
\end{abstract}

\footnotetext{
ABSTRAK

Fokus penelitian ini ialah melakukan penilaian terhadap konten media tentang sengketa Tanah Wakaf di Sumatera Utara. Penelitian ini bertujuan untuk mengidentifikasi informasi yang berguna mengenai sengketa tanah wakaf di Sumatera yang bersumber dari media online yang dapat diakses di internet, dilaksanakan sejak 31 Juli 2019-30 November 2019. Metode yang digunakan pada penelitian ini Systematic literature review (SLR) atau tinjauan pustaka sistematis, yakni metode literature review yang mengidentifikasi, menilai, dan menginterpretasi seluruh temuan-temuan pada suatu topik penelitian untuk menjawab pertanyaan penelitian. Hasil
} 
akhir yang diperoleh dalam penelitian ini menunjukkan bahwa berdasarkan pemberitaan sebanyak 48 media yang memberitakan sengketa wakaf sejak tahun 2007 hingga 2019, terdapat setidaknya kriteria tertentu yang signifikan berdasarkan protokol yang ditetapkan pada penelitian ini: Pertama, dari sisi peruntukan wakaf, sengketa tanah wakaf didominasi pada masjid; Kedua, dari sisi pihak yang bersengketa, didominasi antara umat Islam dan pihak developer; Ketiga: dari sisi lokasi di Sumatera Utara, didominasi di Kota Medan; Keempat: dari sisi tahun terbit didominasi pada tahun 2018; dan Kelima, dari sisi kode media menunjukkan, tidak didominasi oleh karakter media tertentu, yang berarti baik media Islam, media mainstream, media lokal maupun nasional, secara berimbang memuat pemberitaan sengketa wakaf. Hasil evaluasi terhadap data sengketa wakaf yang diungkap media menunjukkan, bahwa secara umum, persoalan sengketa wakaf di Sumatera Utara belum tergambarkan secara menyeluruh di masing-masing daerah. Advokasi yang dilakukan baik secara litigasi maupun non litigasi menunjukkan belum adanya penyelesaian secara tuntas sengketa tanah wakaf di Sumatera Utara.

\section{Pendahuluan}

Permasalahan sengketa tanah wakaf sudah sangat mengkhawatirkan, secara umum, sengketa tanah wakaf merupakan bentuk kegagalan pemerintah dalam implementasi UU. Wakaf. Selain itu, sengketa tanah wakaf juga berkaitan dengan konflik sosial antara umat Islam dengan para preman bayaran yang dari pihak pengembang yang berkepentingan terhadap tanah wakaf yang dikuasai umat Islam.

Dalam sistem perundang-undangan di Indonesia, keberadaan tanah wakaf diakui eksistensinya melalui Undang-Undang Nomor 5 Tahun 1960 tentang Peraturan Dasar Pokok-pokok Agraria, yang sering disebut dengan Undang-undang Pokok Agraria (UUPA) pada bagian XI tentang Hak-hak Tanah untuk Keperluan Suci dan Sosial. Pada Pasal 49 ayat (3) Undang-undang Nomor 5 Tahun 1960 Tentang Peraturan Dasar Pokok-pokok Agraria, perwakafan tanah mendapat perhatian, khusus yang menegaskan bahwa perwakafan tanah milik dilindungi dan diatur dalam peraturan pemerintah. ${ }^{1}$ Dengan terbitnya Undang-Undang No. 41 Tahun 2004 tentang Wakaf, maka eksistensi tanah wakaf semakin diakui.

Definisi Wakaf² menurut UU. No. 41 tahun 2004 tentang Wakaf, adalah perbuatan hukum wakaf (orang yang berwakaf) untuk memisahkan dan/atau menyerahkan sebagian harta benda miliknya untuk dimanfaatkan selamanya atau jangka waktu tertentu sesuai dengan kepentingannya guna keperluan ibadah dan atau kesejahteraan umum menurut syariah. ${ }^{3}$

1 Arief S., ed., UUPA dan Hukum Agraria dan Hukum Tanah dan Beberapa Masalah Hukum AgrariaNo Title (Surabaya: Pustaka Tinta Mas, 1981), 27.

2 Wakaf berasal dari bahasa Arab "waqofa" yang berarti menahan, lihat Muhammad Yunus, Kamus Arab Indonesia (Jakarta: Hidakarya Agung, 1987), 505; Istilah yang semakna dengan wakaf di antaranya habbasa, tahbis, ahbasa, tasbil, lihat Syamsuddin Muhammad, Nihayatul al Muhtaj (Beirut: Darul Fikri, 1984), 358; Lihat juga Ma'luf Louis, Munjid (Beirut: Maktabah Sarkiah, 1986), 914.

3 Mardani, Aspek Hukum Lembaga Keuangan Syariah Di Indonesia (Jakarta: Prenada Media, 2015), 291; Lihat juga di Anas Zarqa, Cara Terkini Mendanai dan Menginvestasikan Harta Wakaf, ed. Hasan Abdullah Al-Amin (Jeddah: Al-Ma'had Al-Islamy li Al-Buhuts wa At-Tadrib, 1989). 
Meskipun eksistensi wakaf telah diakui dan dilindungi eksistensinya oleh Negara, diatur secara jelas secara syariat, namun sengketa tanah wakaf banyak terjadi di Sumatera Utara. Hal ini tergambar secara jelas dari 104 berita dari hasil penelusuran, identifikasi dan analisis yang dilakukan selama kurang lebih 3 bulan. Dari jumlah tersebut, terseleksi sebanyak 48 media yang kemudian dijadikan data untuk dikaji ulang (review) dan dinilai (evaluasi). Review terhadap data-data ini sangat penting dalam menemukan berbagai ciri, karakter dan kecenderungan yang ada pada sengketa tanah wakaf yang terjadi di Sumatera Utara. Data penelusuran dan dibatasi sebagai media online yang dapat diakses, bukan versi cetak. Sehingga sumber-sumber lain seperti media sebuah organisasi nonmedia sebelumnya telah direduksi.

Penelitian ini bertujuan untuk mengidentifikasi informasi peruntukan wakaf, pihak yang bersengketa. lokasi, tahun terbit dan jenis media pada sengketa tanah wakaf di Sumatera yang bersumber dari media online yang dapat diakses di internet.

Manfaat penelitian ini adalah teridentifikasinya peruntukan wakaf, pihak yang bersengketa. lokasi, tahun terbit dan karakter media melalui 48 pemberitaan media yang berbeda terkait sengketa kasus tanah di Provinsi Sumatera Utara. Selain itu, penelitian ini juga diharapkan dapat bermanfaat sebagai referensi bagi para pemerhati wakaf, aparat penegak hukum, para jurnalis sebagai referensi untuk melihat pemberitaan wakaf dari berbagai sisi.

Fokus penelitian ini ialah melakukan penilaian terhadap konten media yang dapat diakses melalui internet. tentang sengketa Tanah Wakaf di Provinsi Sumatera Utara. Dalam merancang proses penilaian, dirancang untuk menemukan peruntukan wakaf, pihak yang bersengketa, tahun terbit dan karakter media yang telah dimuat dan dapat diakses secara online. Penilaian juga dilakukan pada bentuk advokasi yang dilakukan, baik melalui jalur hukum formil (litigasi) maupun jalur kekuatan massa, pengorganisasian massa dan pressure group dan lain-lain (non-litigasi). Parameter litigasi dan non litigasi penting dalam menilai penyelesaian sengketa tanah wakaf. Khususnya dalam penilaian penyelesaian sengketa, evaluasi yang dilakukan ialah evaluasi terhadap bentuk advokasi.

\section{Metode}

Penelitian terkait wakaf ini menggunakan metode Systematic literature review. Systematic literature review atau sering disingkat SLR atau dalam bahasa Indonesia disebut tinjauan pustaka sistematis adalah metode literature review yang mengidentifikasi, menilai, dan menginterpretasi seluruh temuan-temuan pada suatu topik penelitian, untuk menjawab pertanyaan penelitian (research question) yang telah ditetapkan sebelumnya. ${ }^{4}$ Metode SLR dilakukan secara sistematis dengan mengikuti tahapan dan protokol yang memungkinkan proses literature review terhindar dari bias dan pemahaman yang bersifat subyektif dari penelitinya. Systematic Literature Review (SLR) merupakan suatu cara identifikasi,

4 Kitchenham \& Charters, dalam Romi Satria Wahono, "A Systematic Literature Review of Software Defect Prediction: Research Trends, Datasets, Methods and Frameworks," Journal of Software Engineering (2015): 2. 
evaluasi, dan interpretasi semua ketersediaan penelitian yang relevan terhadap rumusan masalah atau area topik yang diteliti. ${ }^{5}$ Kontribusi penelitian individu terhadap systematic review disebut dengan primary studies. Sedangkan systematic review itu sendiri adalah suatu bentuk secondary studies. ${ }^{6}$

Menurut Moh. Hakimi, literatur merupakan proses melihat secara kritis hasil penelitian yang sudah ada. Literatur yang dimaksud yaitu jurnal, buku, laporan, koran, conference, dan lain-lain. Artikel jurnal yang baik memiliki ciri salah satunya up to date. Sementara, untuk jurnal yang open access, lebih mudah dipublikasikan asal memiliki modal. Isu terakhir, biaya penerbitan jurnal di BMJ sebesar 26 Juta per satu jurnal. Buku di negara maju dapat dipilih karena sering merupakan hasil penelitian sendiri yang dibukukan misal Case Study yang disusun Yin. Kemudian, proceeding pertemuan ilmiah sejauh ini dianggap paling up to date, jadi, jarang langsung update. Koran hanya berfungsi untuk informasi kecenderungan/penemuan baru. Untuk tesis dan disertasi, dulu sulit diperoleh, saat ini sudah banyak atau terdigitalisasi. Tujuan membaca tesis dan disertasi orang lain yaitu untuk mendapat standar yang diharapkan. Sumber lain yang dapat digunakan sebagai literatur ialah internet dan majalah. ${ }^{7}$

Dengan demikian, dapat dikatakan bahwa literatur yang menjadi ruang lingkup systematic review tidak terbatas hanya pada laporan penelitian dan publikasi ilmiah semata, melainkan mencakup sumber media, termasuk media online. Dapat dikatakan, penggunaan pemberitaan media online juga relevan untuk dikatakan sebagai objek kajian literatur sistematis.

Tahapan SLR terdiri dari 3 tahapan: (1) Planning, (2) Conducting, dan (3) Reporting. Pada tahap planning, diawali dengan Research Question (RQ). RQ dalam SLR berguna untuk menuntun proses pencarian dan ekstraksi literatur. Analisis dan sintesis data, sebagai hasil dari SLR, adalah jawaban dari RQ yang kita tentukan di depan. RQ yang baik adalah yang bermanfaat, terukur, arahnya ke pemahaman terhadap state-of-the-art research dari suatu topik penelitian. Formulasi RQ harus didasarkan pada lima elemen yang terkenal dengan sebutan PICOC, yaitu: (a) Population (P): Target group dari investigasi; (b) Intervention (I): Aspek detail dari investigasi, atau isu yang menarik bagi peneliti; (c) Comparison (C): Aspek dari investigasi di mana Intervention (I) akan dibandingkan; (d) Outcomes (O): Efek dan hasil dari Intervention (I); dan (e) Context (C): Setting dan lingkungan dari investigasi. Secara umum Protokol SLR biasanya memuat 7 elemen, yaitu: Background, Research Questions, Search terms, Selection criteria, Quality checklist and procedures, Data extraction strategy dan Data synthesis strategy. Setelah tahap planning, tahap conduting adalah tahapan yang berisi pelaksanaan dari SLR, yang perlu disesuaikan dengan Protokol SLR yang telah ditentukan. Misalnya menyeleksi tahun publikasi, tipe

\footnotetext{
Calderon and Ruiz, dalam Ibid.

Kitchenham \& Charters, dalam Ibid.

Pusat Kebijakan dan Manajemen Kesehatan Fakultas Kedokteran Universitas Gadjah Mada, "Cara Mengidentifikasi Masalah Penelitian dan Cara Menyusun Telaah Pustaka," diakses Desember 12, 2020, http://chpm.fk.ugm.ac.id/index.php/id/component/content/article/51-id/613-kuliah-umum-caramengidentifikasi-masalah-penelitian-dan-cara-menyusun-telaah-pustaka.
} 
publikasi dan string (kata kunci) pencarian (search). Pada tahap ini dilakukan analisis dan penilaian terhadap kualitas literatur, yang didasarkan pada lima parameter menyangkut pertanyaan mengenai: (1) proses analisis; (2) analisis residual dan sensitivitas; (3) akurasi statistik; (4) komparasi; dan (5) ukuran dari data set yang digunakan. ${ }^{8}$

Dengan demikian, tahapan dari Systematic Literature Review pada penelitian ini adalah (1) mengklasifikasi, (2) mengidentifikasi, (3) mengumpulkan dan (4) menganalisis pemberitaan tentang sengketa tanah wakaf di Sumatera Utara yang bersumber di media yang dapat diakses melalui internet. Sehingga dalam konteks penelitian ini, tahap SLR dilakukan terhadap konten berita tentang sengketa tanah wakaf khususnya berkaitan dengan 5 protokol yang relevan dengan unsur berita $(5 \mathrm{~W} 1+1 \mathrm{H})$ dikaitkan dengan kriteria sengketa wakaf, yaitu: (1) jenis peruntukan wakaf (2) pihak yang bersengketa; (3) lokasi sengketa berdasarkan Kab/Kota di Sumatera Utara; (4) tahun pemberitaan (terbit); dan (5) kode sumber media. Dalam melakukan studi literatur terhadap media tentang pemberitaan sengketa tanah wakaf ini didapatkan bahwa kata kunci yang relevan ialah: "sengketa tanah wakaf." Pada tahap analisis, dilakukan coding terhadap 25 media baik nasional maupun lokal, baik media mainstream maupun media Islam. Setelah pengkodingan dilakukan, dilanjutkan dengan mengidentifikasi sengketa wakaf berdasarkan intensitas pemberitaan masing-masing berdasarkan peruntukan wakaf, pihak yang bersengketa, lokasi, tahun terbit (dimuat) dan evaluasi terhadap bentuk advokasi yang dilihat berdasarkan dua bentuk, yaitu litigasi dan non-litigasi). Semua intensitas pemberitaan tersebut kemudian dihitung, dimaknai dan diberi penilaian.

\section{Sengketa Tanah Wakaf di Sumatera Utara (Systematic Literature Review Terhadap Pemberitaan Media Online)}

\subsection{Hasil penelitian}

Penelitian Systematic Literature Review terhadap pemberitaan media tentang Perampasan Tanah Wakaf di Sumatera Utara ini ditetapkan berdasarkan 5 protokol yang relevan dengan unsur berita (5 W $1+1 \mathrm{H}$ ) dikaitkan dengan kriteria sengketa wakaf, yaitu: (1) jenis peruntukan wakaf (2) pihak yang bersengketa; (3) lokasi sengketa berdasarkan Kab/Kota di Sumatera Utara; (4) tahun pemberitaan (terbit); dan (5) kode sumber media. Selanjutnya, evaluasi dilakukan terkait bentuk advokasi penyelesaian sengketa.

Berdasarkan penelusuran data pemberitaan yang dilaksanakan sejak 31 Juli 2019-30 November 2019, menunjukkan hasil analisis parameter (protokol) sebagai berikut:

Tabel 1. Hasil analisis parameter (protokol).

\begin{tabular}{llllll}
\hline CODE & Peruntukan & Pihak Bersengketa & Lokasi & Tahun & Advokasi \\
\hline $1(\mathrm{TR})$ & Pendidikan & Ahli Waris-Yayasan & Medan & 2019 & $\begin{array}{l}\text { Litigasi Ormas Islam } \\
\text { Non-litigasi warga }\end{array}$
\end{tabular}

8 Wahono, "A Systematic Literature Review of Software Defect Prediction: Research Trends, Datasets, Methods and Frameworks," 2. 


\begin{tabular}{|c|c|c|c|c|c|}
\hline 2 (SP) & Rumah sakit & Umat Islam-Pemprov & Medan & 2018 & $\begin{array}{l}\text { Litigasi Ormas Islam } \\
\text { Non-litigasi umat Islam }\end{array}$ \\
\hline 3 (SIB) & Rumah sakit & Umat Islam-Pemprov & Medan & 2014 & $\begin{array}{l}\text { Litigasi Ormas Islam } \\
\text { Non-litigasi umat Islam }\end{array}$ \\
\hline 4 (MO) & Masjid & Umat Islam-Developer & Medan & 2019 & Non-litigasi umat Islam \\
\hline 5 (WS) & Masjid & Umat Islam-Developer & Medan & 2018 & Non-litigasi umat Islam \\
\hline 6 (WS) & Asrama-RS & Umat Islam-Developer & Medan & 2018 & $\begin{array}{l}\text { Litigasi Ormas Islam } \\
\text { Non-litigasi umat Islam }\end{array}$ \\
\hline 7 (WS) & Asrama-RS & Umat Islam-Developer & Medan & 2019 & $\begin{array}{l}\text { Litigasi Ormas Islam } \\
\text { Non-litigasi umat Islam }\end{array}$ \\
\hline 8 (VOI) & Masjid & Umat Islam-Developer & Medan & 2012 & Non-litigasi umat Islam \\
\hline 9 (WS) & Masjid & Umat Islam-Developer & Medan & 2018 & Non-litigasi umat Islam \\
\hline $10(\mathrm{SP})$ & Masjid & Umat Islam-Developer & Medan & 2018 & Non-litigasi umat Islam \\
\hline 11(RP) & Masjid & Umat Islam-Developer/Kodam & Medan & 2011 & Non-litigasi umat Islam \\
\hline $12(\mathrm{WS})$ & Asrama-RS & Umat Islam-Developer & Medan & 2015 & $\begin{array}{l}\text { Litigasi Ormas Islam } \\
\text { Non-litigasi umat Islam }\end{array}$ \\
\hline $13(\mathrm{MB})$ & Rumah sakit & Umat Islam-Pemprov & Medan & 2014 & $\begin{array}{l}\text { Litigasi Ormas Islam } \\
\text { Non-litigasi umat Islam }\end{array}$ \\
\hline 14 (HD) & Masjid & OTK (pembakaran) & Taput & 2010 & Non-litigasi umat Islam \\
\hline $15(\mathrm{RP})$ & Masjid & Umat Islam-Developer/Kodam & Medan & 2011 & Non-litigasi umat Islam \\
\hline $16(\mathrm{MR})$ & Masjid & Umat Islam-Developer & Medan & 2019 & Non-litigasi umat Islam \\
\hline 17 (EM) & Masjid & Umat Islam-Developer/Kodam & Medan & 2011 & Non-litigasi umat Islam \\
\hline 18 (NM) & Masjid & Umat Islam-Developer/Kodam & Medan & 2011 & Non-litigasi umat Islam \\
\hline 19 (VOI) & Masjid & Umat Islam-Developer/Kodam & Medan & 2011 & Non-litigasi umat Islam \\
\hline $20(\mathrm{SP})$ & Pendidikan & Internal Yayasan & Binjai & 2019 & Litigasi Ormas Islam \\
\hline $21(\mathrm{DW})$ & Masjid & Umat Islam-Developer/Kodam & Medan & 2011 & Non-litigasi umat Islam \\
\hline $22(\mathrm{KK})$ & Masjid & Umat Islam-Developer & Medan & 2019 & Non-litigasi umat Islam \\
\hline 23 (VOI) & Masjid & OTK (pembakaran) & Taput & 2010 & Non-litigasi umat Islam \\
\hline 24 (HD) & Masjid & Umat Islam-Developer & Medan & 2007 & Non-litigasi umat Islam \\
\hline 25 (RT) & Masjid & OTK (pembakaran) & Taput & 2015 & Non-litigasi umat Islam \\
\hline $26(\mathrm{SP})$ & Masjid & Int. BKM perusakan & Medan & 2018 & Non-litigasi umat Islam \\
\hline $27(\mathrm{SP})$ & Masjid & Umat Islam-Developer & Medan & 2012 & $\begin{array}{l}\text { Litigasi Ormas Islam } \\
\text { Non-litigasi umat Islam }\end{array}$ \\
\hline $28(\mathrm{SP})$ & Masjid & Umat Islam-Developer & Medan & 2018 & Litigasi Ormas Islam \\
\hline 29 (TR) & Pendidikan & Nadzir (kriminalisasi) & Medan & 2012 & $\begin{array}{l}\text { Litigasi TPM Medan } \\
\text { Non-litigasi umat Islam }\end{array}$ \\
\hline 30 (RRI) & Rumah sakit & Umat Islam-Pemprov & Medan & 2018 & $\begin{array}{l}\text { Litigasi Ormas Islam } \\
\text { Non-litigasi umat Islam }\end{array}$ \\
\hline 31(KK) & Masjid & Umat Islam-Developer & Medan & 2019 & Non-litigasi umat Islam \\
\hline
\end{tabular}




\begin{tabular}{|c|c|c|c|c|c|}
\hline 32 (IN) & Masjid & Umat Islam-Developer & Medan & 2018 & Non-litigasi umat Islam \\
\hline 33 (TR) & Masjid & Umat Islam-Developer & Medan & 2012 & $\begin{array}{l}\text { Litigasi Ormas Islam } \\
\text { Non-litigasi umat Islam }\end{array}$ \\
\hline $34(\mathrm{OR})$ & Pendidikan & Yayasan-Pemilik rumah mewah & Medan & 2018 & Litigasi yayasan \\
\hline $35(\mathrm{IM})$ & Pendidikan & Nazhir-warga & Medan & 2019 & Non-litigasi warga \\
\hline $34(\mathrm{KP})$ & Masjid & Umat Islam-Developer & Medan & 2012 & $\begin{array}{l}\text { Litigasi Ormas Islam } \\
\text { Non-litigasi umat Islam }\end{array}$ \\
\hline $35(\mathrm{KM})$ & Masjid & Umat Islam-Developer & Medan & 2018 & Non-litigasi umat Islam \\
\hline 36 (VOI) & Masjid & Umat Islam-Developer & Medan & 2011 & Non-litigasi umat Islam \\
\hline 37 (KP) & Masjid & Umat Islam-Developer & Medan & 2012 & $\begin{array}{l}\text { Litigasi Ormas Islam } \\
\text { Non-litigasi umat Islam }\end{array}$ \\
\hline 38 (VOI) & Masjid & Umat Islam-Developer & Medan & 2012 & $\begin{array}{l}\text { Litigasi Ormas Islam } \\
\text { Non-litigasi umat Islam }\end{array}$ \\
\hline 39 (WS) & Asrama-RS & Umat Islam-Developer & Medan & 2019 & $\begin{array}{l}\text { Litigasi Ormas Islam } \\
\text { Non-litigasi umat Islam }\end{array}$ \\
\hline 40 (LP) & Pekuburan & Lurah-Warga & Medan & 2009 & Non-litigasi warga \\
\hline $41(\mathrm{MB})$ & Masjid & Umat Islam-Developer & Medan & 2018 & Non-litigasi umat Islam \\
\hline $42(\mathrm{EM})$ & Masjid & OTK (pembakaran) & Taput & 2011 & Non-litigasi umat Islam \\
\hline 43 (HD) & Pendidikan & Nadzir (kriminalisasi) & Medan & 2012 & $\begin{array}{l}\text { Litigasi TPM Medan } \\
\text { Non-litigasi umat Islam }\end{array}$ \\
\hline 44 (HD) & Masjid & Umat Islam-Developer/Kodam & Medan & 2011 & Non-litigasi umat Islam \\
\hline $45(\mathrm{SM})$ & Masjid & Umat Islam-Developer & Medan & 2018 & Non-litigasi umat Islam \\
\hline 46 (TB) & Masjid & Umat Islam-Developer & Medan & 2018 & Non-litigasi umat Islam \\
\hline 47 (TR) & Masjid & Umat Islam-Developer & Medan & 2018 & Non-litigasi umat Islam \\
\hline 48 (TBS) & Masjid & Umat Islam-Developer & Medan & 2018 & Non-litigasi umat Islam \\
\hline $48(\mathrm{SW})$ & Masjid & Umat Islam-Developer & Medan & 2018 & Non-litigasi umat Islam \\
\hline
\end{tabular}

Sumber: Primary data, 2019.

\subsection{Peruntukan Wakaf}

Data sebanyak 48 pemberitaan dari hasil yang seleksi pencarian, diperoleh gambaran bahwa sengketa tanah di Sumatera Utara didominasi terkait sengketa tanah adalah masjid. Berdasarkan tabel 1 dapat dilihat bahwa, sengketa wakaf di Sumatera Utara dapat menurut peruntukannya, didominasi oleh sengketa terhadap tanah masjid (ada juga perobohan/pembongkaran/pembakaran dan perusakan masjid) dengan total 33, diikuti terkait tanah wakaf untuk pendidikan sebanyak 6, asrama merangkap rumah sakit dan rumah sakit (saja) masing-masing 4, dan pekuburan terdapat 1 kali pemberitaan.

Tabel 2. Analisis Berita Sengketa Tanah Wakaf berdasarkan Peruntukan Wakaf.

\begin{tabular}{cccc}
\hline No. & & Peruntukan & Jumlah \\
\hline 1. & Masjid & & 33
\end{tabular}


2. Pendidikan

3. Asrama dan RS

4. Rumah Sakit

5. Perkuburan

Total

\subsection{Pihak yang Bersengketa}

Dari hasil pencarian, identifikasi, seleksi dan analisis terhadap 48 pemberitaan media (tabel 2), dapat digambarkan, bahwa sebagian besar sengketa wakaf di Sumatera Utara didominasi sengketa antara umat Islam dengan pihak pengembang (developer), yakni sebanyak 26 item dari 48 berita, disusul antara 7 kali pemberitaan antara umat Islam dengan developer yang melibatkan Kodam (I/BB). Karakter pemberitaan ini fokus pada permasalahan Masjid al Ikhlas yang pemberitaannya pernah mencuat pada tahun 2011. Selanjutnya 4 berita terkait RS Haji Medan, sebanyak 4 kali, antara umat Islam yang secara representatif disuarakan oleh belasan ormas Islam di Sumatera Utara menghadapi Pemprovsu yang dinilai telah mengalih fungsikan status tanah wakaf.

Tabel 3. Analisis Berita Sengketa Tanah Wakaf berdasarkan Pihak Bersengketa.

\begin{tabular}{clc}
\hline No. & \multicolumn{1}{c}{ Pihak Bersengketa } & Jumlah \\
\hline 1. & Umat Islam-Developer & 26 \\
2. & Umat Islam-Developer/Kodam & 7 \\
3. & Umat Islam-Pemprov & 4 \\
4. & OTK (pembakaran) & 4 \\
5. & Nazhir-warga & 2 \\
6. & Ahli Waris-Yayasan & 1 \\
7. & Lurah-warga & 1 \\
8. & Nadzir (kriminalisasi) & 1 \\
9. & Yayasan-Pemilik rumah mewah & 1 \\
10. & Internal yayasan & 1 \\
& Total & $\mathbf{4 8}$ \\
\hline
\end{tabular}

Sumber: Primary data, 2019.

\subsection{Lokasi}

Berdasarkan analisis terhadap lokasi sengketa wakaf yang diungkap 48 pemberitaan media online yang dapat diakses secara langsung (tabel 3), menunjukkan sengketa wakaf di Sumatera Utara didominasi oleh Kota Medan sebanyak 43 pemberitaan (tabel 3), disusul Taput dan Binjai. Dalam penelusuran juga ditemukan data-data yang menunjukkan daerah (Kabupaten/Kota) lainnya di Sumatera Utara, tetapi tidak memenuhi kriteria penelitian ini, yakni tidak dimuat oleh media online yang dapat diakses langsung, melainkan diterbitkan dalam penelitian, blog, media sebuah organisasi yang bukan media dan sebagainya, atau pemberitaan yang pernah terbit di media cetak tetapi tidak lagi dapat diakses secara online. 
Tabel 4. Analisis Berita Sengketa Tanah Wakaf berdasarkan Lokasi (Kab/Kota di Sumut).

\begin{tabular}{|c|c|c|}
\hline No. & Lokasi & Jumlah \\
\hline 1. & Medan & 43 \\
\hline 2. & Tapanuli Utara & 4 \\
\hline \multirow[t]{2}{*}{3.} & Binjai & 1 \\
\hline & Total & 48 \\
\hline
\end{tabular}

Sumber: Primary data, 2019.

Tahun terbit cukup memberikan kriteria tertentu pada pemberitaan mengenai sengketa tanah wakaf, misalnya kasus ruishlagh Masjid al Ikhlas Jalan Timor yang mencuat, khusus pada tahun 2011. Data 48 media (tabel 4) menunjukkan, penelusuran terhadap sengketa tanah wakaf di Sumatera Utara telah terendus media online dan masih dapat diakses hingga saat ini tercatat sejak tahun 2007. Sedangkan intensitas pemberitaan sengketa tanah wakaf yang paling menonjol ditemukan pada tahun 2018, dengan berbagai kasus yang variatif, sebagaimana yang dideskripsikan pada protokol lain pada penelitian ini, disusul tahun 2019 dan 2012, masing-masing tercatat sebanyak 8 berita.

Tabel 5. Analisis Berita Sengketa Tanah Wakaf berdasarkan Tahun (Terbit).

\begin{tabular}{|c|c|c|}
\hline No. & Tahun Terbit & Jumlah \\
\hline 1. & 2018 & 15 \\
\hline 2. & 2019 & 8 \\
\hline 3. & 2012 & 8 \\
\hline 4. & 2011 & 6 \\
\hline 5. & 2015 & 5 \\
\hline 6. & 2014 & 2 \\
\hline 7. & 2010 & 2 \\
\hline 8. & 2009 & 1 \\
\hline \multirow[t]{2}{*}{9.} & 2007 & 1 \\
\hline & Total & 48 \\
\hline
\end{tabular}

Sumber: Primary data, 2019.

\subsection{Kode Sumber}

Kode sumber (tabel 5) menunjukkan, 48 berita yang di-review pada penelitian merupakan hasil pencarian dari pemberitaan 25 media online yang dapat diakses di internet. Kriteria yang menonjol tidak ditemukan antara media mainstream dan Islam, maupun media lokal dan nasional. Perbedaan konteks pemberitaan sengketa tanah wakaf oleh masing-masing media mainstream, lebih pada isu sengketa wakaf tersebut melibatkan banyak pihak dan adanya gesekan politik dan bisnis. Kendari demikian, tidak semua media Islam online juga yang menonjolkan atau menampilkan argumentasi dalil-dalil (dogma) keagamaan.

Tabel 6. Analisis Berita Sengketa Tanah Wakaf berdasarkan Kode Sumber.

\begin{tabular}{ccc}
\hline No. & Kode Sumber & Jumlah \\
\hline 1. & SP & 6 \\
2. & HD & 5 \\
3. & WS & 5 \\
4. & TR & 4
\end{tabular}




\section{5.}

6.

7.

8.

9.

10.

11.

12.

13.

14.

15.

16.

17.

18.

19.

20.

21.

22.

23.

24.

25.

$\begin{array}{cc}\text { EM } & 2 \\ \text { MB } & 2 \\ \text { RP } & 2 \\ \text { VOI } & 3 \\ \text { KP } & 2 \\ \text { KK } & 2 \\ \text { IM } & 1 \\ \text { OR } & 1 \\ \text { IN } & 1 \\ \text { LP } & 1 \\ \text { RRI } & 1 \\ \text { SW } & 1 \\ \text { DW } & 1 \\ \text { NM } & 1 \\ \text { EM } & 1 \\ \text { KM } & 1 \\ \text { MO } & 1 \\ \text { SIB } & 1 \\ \text { TBS } & 1 \\ \text { TB } & 1 \\ \text { SM } & 1 \\ \text { Total } & 1 \\ & \mathbf{4 8}\end{array}$

Sumber: Primary data, 2019.

\subsection{Evaluasi Advokasi}

Data pemberitaan 25 media, di 48 pemberitaan sejak 2007-2019 memperlihatkan bahwa sengketa tanah wakaf di Sumatera Utara lebih didominasi advokasi berbentuk non-litigasi (tabel 7), hanya 9 berita yang menunjukkan bahwa sengketa tanah wakaf dibela secara jalur hukum dan pressure group dan sebagainya berupa non-litigasi dan 6 berita yang secara hukum mendapat pembelaan dari jalur hukum oleh Ormas Islam dan secara nonlitigasi oleh umat Islam secara umum. Selain itu terdapat pula advokasi non-litigasi warga, litigasi yayasan dan litigasi tim pengacara yang tidak melibatkan umat Islam (ormas) secara luas.

Tabel 3. Evaluasi Sengketa Tanah Wakaf berdasarkan Bentuk Advokasi.

\begin{tabular}{clc}
\hline No. & \multicolumn{1}{c}{ Bentuk Advokasi } & Jumlah \\
\hline 1. & Litigasi Ormas Islam dan Non-litigasi warga. & 9 \\
2. & Litigasi Ormas Islam dan Non-litigasi umat Islam. & 6 \\
3. & Hanya Non-litigasi umat Islam. & 30 \\
4. & Hanya litigasi Ormas Islam. & 2 \\
5. & Non-litigasi warga. & 2 \\
6. & Litigasi yayasan. & 1 \\
7. & Litigasi lawyer lainnya (TPM) Non-litigasi umat Islam. & 1 \\
& Total & $\mathbf{4 8}$ \\
\hline
\end{tabular}

Sumber: Primary data, 2019. 


\section{Kesimpulan}

Hasil yang diperoleh menunjukkan bahwa penelitian tentang sengketa tanah wakaf di Sumatera Utara berdasarkan 48 pemberitaan media yang dapat diakses secara online menunjukkan bahwa secara umum bahwa kelima protokol yang ditetapkan pada penelitian ini terjawab dan dapat diekstrak dari sumber-sumber media tersebut.

Sengketa tanah wakaf yang muncul dalam pemberitaan, jika di-review dari 48 media online yang diakses pada penelitian ini memperlihatkan karakteristik tertentu. Karakteristik tersebut dikembangkan dari lima protokol yang dikembangkan terkait topik penelitian ini yakni sengketa wakaf di Sumatera Utara telah diberitakan di media online sejak tahun 2007. Hingga 2019, terdapat setidaknya ditemukan kriteria yang signifikan baik berdasarkan peruntukan wakaf, pihak yang bersengketa, lokasi dan tahun serta evaluasi terhadap advokasi yang dilakukan.

Dengan demikian, sesuai protokol yang ditetapkan pada penelitian review ini dapat disimpulkan: Pertama, dari sisi peruntukan wakaf, sengketa tanah wakaf didominasi pada masjid; Kedua, dari sisi pihak yang bersengketa, didominasi antara umat Islam dan pihak developer; Ketiga: dari sisi lokasi di Sumatera Utara, didominasi di Kota Medan; Keempat: dari sisi tahun terbit didominasi pada tahun 2018; dan Kelima, dari sisi kode media menunjukkan, tidak didominasi oleh karakter media tertentu, yang berarti baik media Islam, media mainstream, media lokal maupun nasional, secara berimbang memuat pemberitaan sengketa wakaf.

Dari sisi pembelaan, hasil penilaian yang dilakukan terhadap sengketa tanah wakaf menunjukkan bahwa dari 48 berita yang dipilih, memperlihatkan bahwa sengketa tanah wakaf di Sumatera Utara masih sangat minim data di daerah lain di Sumatera Utara di luar kota Medan, bahkan minim pembelaan. Tercatat hanya 16 berita yang memperlihatkan adanya upaya litigasi dan non-litigasi yang dilakukan bersama (Ormas-ormas Islam) dan tidak memperlihatkan adanya kekuatan hukum tetap, bahkan ada yang kalah di pengadilan. Pembelaan lain ada yang melalui jalur hukum, sudah menang tetapi tidak pernah dieksekusi oleh pengadilan dan tidak mendapatkan pembelaan dari umat Islam secara umum. Ada pula mengandalkan pengorganisasian dan pressure group (non-litigasi) secara sporadis tanpa melibatkan pihak-pihak yang berkompeten.

Hasil ini diharapkan dapat memberikan informasi kepada peneliti atau pemerhati hukum wakaf yang tertarik untuk menindaklanjuti informasi terkait perampasan tanah wakaf. Penelitian ini juga bermanfaat untuk meningkatkan perlindungan terhadap tanah wakaf terkait fungsi kontrol sosial media dalam menyajikan fakta kepada masyarakat. Penelitian ini dapat dikembangkan dengan melakukan penelitian kualitatif murni dengan melakukan wawancara langsung terhadap pemilik media setidaknya beberapa orang redaktur senior atau akademisi yang memiliki keahlian bidang yang terkait. 


\section{Daftar Pustaka}

Louis, Ma'luf. Munjid. Beirut: Maktabah Sarkiah, 1986.

Mardani. Aspek Hukum Lembaga Keuangan Syariah Di Indonesia. Jakarta: Prenada Media, 2015.

Muhammad, Syamsuddin. Nihayatul al Muhtaj. Beirut: Darul Fikri, 1984.

Pusat Kebijakan dan Manajemen Kesehatan Fakultas Kedokteran Universitas Gadjah Mada. "Cara Mengidentifikasi Masalah Penelitian dan Cara Menyusun Telaah Pustaka." Diakses Desember 2020. http://chpm.fk.ugm.ac.id/index.php/id/component/content/article/51-id/613kuliah-umum-cara-mengidentifikasi-masalah-penelitian-dan-cara-menyusuntelaah-pustaka.

S., Arief, ed. UUPA dan Hukum Agraria dan Hukum Tanah dan Beberapa Masalah Hukum AgrariaNo Title. Surabaya: Pustaka Tinta Mas, 1981.

Wahono, Romi Satria. "A Systematic Literature Review of Software Defect Prediction: Research Trends, Datasets, Methods and Frameworks." Journal of Software Engineering (2015).

Yunus, Muhammad. Kamus Arab Indonesia. Jakarta: Hidakarya Agung, 1987.

Zarqa, Anas. Cara Terkini Mendanai dan Menginvestasikan Harta Wakaf. Diedit oleh Hasan Abdullah Al-Amin. Jeddah: Al-Ma'had Al-Islamy li Al-Buhuts wa At-Tadrib, 1989. 